Journal of Development and Communication Studies, Vol. 7. Nos. 1 \& 2, January- December, 2020 ISSN (Online \& Print): 2305-7432.

\title{
http://www.devcomsjournalmw.org
}

\section{Use of ICTS for socio-economic development of marginalised communities in rural areas: Proposals for establishment of sectoral Rural Entrepreneurial Networks}

Geraldine Taponeswa Nyika, Department of Information Science, University of South Africa, South Africa. Email: geralnyika@gmail.com

\begin{abstract}
Information, Communication, Technology and Services (ICTS) is increasingly being used in various fields that include agriculture, education, medicine, tourism and business. However, due to challenges caused by the digital divide and other factors, the use of ICTS and its contribution to socio-economic development is generally more intense in developed countries than in developing countries, and also more in urban areas than in rural areas. This article gives an overview of ICTS, the extent of its adoption in different fields, factors that hinder ICTS driven socio-economic development in developing countries and rural areas, and various possible ways of maximizing potential benefits that marginalised communities can derive from the limited ICTS that is accessible to them.
\end{abstract}

Keywords: ICTS, development, marginalised, rural, networks. https://doi.org/10.4314/jdcs.v7i1-2.5

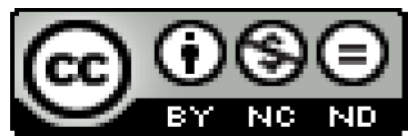

(C) 2020. The author. This work is licensed under the Creative Commons Attribution 4.0 International License (CC-By-NC-ND). Users may freely share and redistribute this work provided that the author and the Journal of Development and Communication Studies are fully acknowledged. Users may not tweak or remix and offer this work for sale. The full license may be accessed at https://creativecommons.org/licenses/by-nc-nd/4.0/

\section{Introduction}

The term ICT stands for two slightly different terminologies. The first one is 'Information and Communication Technology' (ICT), which is made up of two components, namely (i) information technology and (ii) communication technology. The 2-component terminology implies that ICT is about the technology of information and the technology of communication, without covering information as a field on its own and communication as a field on its own. Thus, the 2-component terminology combines information and communication into one term and looks at the technology of that one combined term. The second terminology is 'Information, Communication and 
Technology' (ICT), which is made up of three components, namely (a) information, (b) communication, and (c) technology. The second terminology is broader than the first one because it covers information and communication as separate standalone fields in addition to the technology for those separate fields. The terminology can be broadened further by including ICT services rendered, so that it becomes Information, Communication, Technology and Services (ICTS). In this article, the terminology 'ICTS' is used.

In simple terms, Information, Communication and Technology (ICT) refers to a system of computer, telephone and or audio-visual networks that can be used to manage information (Giles, 2018). This article incorporates ICT services into this definition. ICTS tools include computers, telephones, televisions, radios and satellite systems. Information refers to information (or data) in electronic or paper form which has to be handled well through appropriate procedures and standards. Communication is a field on its own and can be through various channels with relevant modalities and regulations. The channels of communication include writing, voice, telecommunication, or broadcasting methods (Giles, 2018). Information Technology consists of software, hardware, and electronics which are used to receive, store, manipulate, transmit or extract information (Fulk and Connie Yuan, 2017). Communication Technology includes tools, software and hardware that are used for communication purposes (Jamal, 2015).

Information and Communication technologies are infrastructures and components that allow modern computing. These networks and system components allow organizations, businesses, and people to communicate on a digital platform. ICTS application has been notable in the areas of agriculture (Takahashi et al., 2020), health (Chib et al., 2015), education (Donou-Adonsou, 2019), climate change (Komendantova et al., 2019), and other fields. The most notable impact has been in tourism, social media, among people with disabilities (PWDs) and in developing countries (Rouse and Margaret 2017).

The most significant development that ICTS has brought about is the internet. The internet is a modern technology that has made it possible to search for and access information from any corner of the world. Sharing and accessing $\mathrm{f}$ information is done by connecting computers on the internet. Through the network created by the connected computers, individuals can send information, messages, photos, videos, and audio to any device connected to the internet, no matter how big or small.

\section{Use of ICTS in various fields}

ICTS is increasingly being used in a wide range of fields of specialisation globally. The extent of utilisation of different aspects of ICTS differs from one field to another. For instance, mobile phones may be used more extensively in one field than others while use of computers may be to some extent universal, cutting across several different fields. Examples of some uses of ICTS in such fields as agriculture, tourism, education, health, 
marketing and e-commerce are given in the next sections. Nevertheless, this is not an exhaustive list of uses of ICTS in various fields.

\section{Use of ICTS in agriculture}

Agriculture is a vital sector because it produces food which is one of basic needs of humans. There are many different uses of ICTS in agriculture that have enhanced efficiency and production. For instance, ICTS is used as part of agricultural systems that control the environment for optimal growth of plants in hydroponic, aquaponic and aeroponic agriculture (AlShrouf, 2017). Websites which make use of ICTS have been created to give farmers access to information on how to improve their farming techniques, efficient methods of farming, weather and other factors that are relevant to farming (Yonazi et al., 2012).

Smartphone applications that enable farmers and farmhands to review the status of their crops or control their irrigation systems remotely have also been created (Mandi and Patnaik, 2019). Phones also give farmers access to chat groups, newsletters, blogs, and bulletins that are meant for farmers to share information, experiences and ideas. Some of these groups or online clubs are made with the location as pre-requisite for admission, which enables farmers to be in contact with other farmers from different localities without having to physically travel (Kabbiri et al., 2018).

Meteorological offices are now using advanced ICTS-based tools to keep the public informed about the weather. The tools used are in the form of social media (Olson et al., 2019), phone applications and elaborate news on the weather (Sugg et al., 2020). It is now possible to check on a smartphone even when it is offline because smartphones have a functionality that enables them to automatically update the day's weather when the phone is connected to internet (Milton et al., 2016).

Due to the worldwide scarcity of water in the world, information technology and water experts around the world have combined forces to explore solutions through ICTS. Hydro-informatics systems use simulation modelling to solve problems of hydraulics, hydrology, and environmental engineering to better manage water systems (Rohila et al., 2017). The information gathered is combined and conveyed using interactive graphs, videos, pictures, and audios. Complete reports can be published as hardcopies or soft copies. ICTS is used for the promotion, marketing, transmission and sharing of the reports and drives as well as cloud are used to store the information for later use (Rohila, Yadav and Ghanghas, 2017).

Modern tools that use ICTS have enabled remote data collection for agricultural purposes, which has gradually replaced manual methods of collecting pertinent data (Schwalbert et al., 2020). Examples of the modern tools include meters and sensors which are used to regulate water distribution systems such as flow and water quality (Ahmed et al., 2014). In terms of communication infrastructure, ICTS has enabled water utility networks to have monitoring systems that automatically detect leakages (Yazdekhasti et 
al., 2020), predict demand for water (Lee and Derrible, 2020), monitor water quality (Topp et al., 2020) and implement billing (Yazdekhasti et al., 2020).

One of the technologies that is being used in e-agriculture is mobile phones. GPS systems, barcode scanners, RFID readers, and smart card readers are all tools that phones can use to save data. Programmes, such asGSMA's Agri programme were designed to develop agricultural information that can help to increase farmers' income and productivity, reduce barriers that farmers in developing countries face, test and prove models of delivery, and promote a culture of sharing information (Agco and Summit, 2012). The program is made up of sub-Saharan African countries and any farmers in that area can join the program as long as they have a mobile phone (Agco and Summit, 2012).

Mobile farming, also known as mobile e-agriculture, enables traceability, hence if a customer is not satisfied with a product it can be traced back to the farmer who produced it. Mobile agriculture is used in forestry, livestock, aquaculture, and greenhouses. It enables farmers to receive important information such as weather forecasts, agricultural products in demand and market prices. Mobile e-agriculture also enables insurance for the farming sector, which is very important due to the advent of climate change that is making the weather increasingly unpredictable (Agco and Summit, 2012). It facilitates communication between insurers and the insured farmers who may be located far away.

Satellite imagery can be used to provide information on crop growth, humidity, and the nutrient needs of farmers' crops (Theunissen, 2015). Depending on the nutritional needs of the crops, expected weather and the date of last irrigation, specialists can determine the best time to irrigate, when to apply fertilizer and other crop husbandry advice. The expert advice can then be communicated to the farmer via the mobile phone. This improves crop yield and water management (Theunissen, 2015). Irrigation increases the yield of the crops, but in most developing countries there is often drought. The use of ICTS can help regulate irrigation and make the process efficient so that crops have their required levels of moisture. The cost of investing in the ICTS based irrigation systems is low relative to the benefits that the farmers will gain (Agco and Summit, 2012).

\section{Use of ICTS in Tourism}

Tourism is a multidimensional industry that not only attracts local and international tourists, but also involves transporting, housing, serving and entertaining them. Tourism destinations are much more attractive to tourists when everything is offered in packages, from their stay to their excursions (Moliner et al., 2007). Hence it would be wise for businesses in tourism to invest their capital in not only tourist attractions, but also in owning or partnering with hotels, transport companies and restaurants in order to provide a full value chain.

With the widespread increase in access to and use of ICTS by the general public (Kavoura and Stavrianea, 2014), the tourism industry has found ICTS tools such as social 
media and the internet to be essential for its sustainability, growth and return on investments (Hoffman and Fodor, 2010). In tourism, ICTS is used mainly for marketing, sales, networking with trading partners and as a source of information (Shanker, 2008). Tourists select their products well before they travel, from selecting their destinations to the specific sights to be seen (Buhalis, 1998). This means that tourists need adequate information that enables them to select products they will enjoy the most. Information can be found on blogs, websites, travel wikis, RSS (Really Simple Syndication), podcasts, online videos, online radios and social media (Sun et al., 2020).

The three most crucial ICTS innovations that have drastically changed tourism are the internet, the Computerized Reservation Systems (CRS) and the Global Distribution System (GDS) (Adeyinka-ojo et al., 2019). CRS is an electronic database that gives information on flights that can be pre-screened, travel policy, flight time, airline preference and ground transportation costs associated with particular airports. It arranges and schedules connecting flights and trips, creates an itinerary of departure and arrival and gives several options for customers to choose from; this can all be done simultaneously (Bhavani, 2020). GDS is a network connection that integrates automated booking systems of different organizations (Shobhana and Gill, 2019). The network can only be accessed by professionals. Proper maintenance is ensured and many airlines and hotels make use of and provide information to the network (Shanker, 2008).

\section{Use of ICTS in Education}

ICTS has been incorporated in schools in recent years. Nowadays, students use elearning, e-books, and devices such as laptops and smartphones. The use of ICTS in libraries is increasing globally. The participation of libraries in knowledge and information societies (KIS) could help to enhance the use of ICTS in libraries; hence the importance of active involvement of libraries in KIS has been emphasised (Ocholla, 2009). Many schools have reduced the number of physical textbooks that students carry to school by opting to have textbooks on their smart devices (Elias et al., 2012). At some schools that have put in place the necessary ICTS infrastructure, teachers send homework to students through e-mail (Hartley, 2007). They also use e-mail, SMS, newsletters and chat groups to send feedback, and update parents on their children's performance and class behaviour (Mohammed et al., 2017). E-learning has reduced distance and location as barriers to learning. Learners are now able to study anywhere they are as long as they have internet and smart devices, such as a laptop, a phone, or a smartphone. There are two types of e-learning, synchronous and asynchronous e-learning (Mohammed et al., 2017). Synchronous e-learning is one that is done with a tutor or instructor. Both the student(s) and instructor must be present for the lesson. Real-time media is used to facilitate the lesson, for example, chat or skype. Asynchronous e-learning is self-paced

learning that does not require the student and teacher to be present simultaneously. The 
leaner downloads coursework through the internet and uploads tasks like assignments and homework through the web (Mohammed et al., 2017).

Public schools that are equipped with facilities like projectors, computers and tablets expose pupils to technology that is becoming an integral part of work and day to day living. With exposure comes the chances to learn how to use computers, tablets and projectors. Such exposure not only enables hands-on learning of how to practically use ICTS gadgets but also enables the schools to offer such subjects as Information and Technology (IT), Information, Communication, Technology and Services (ICTS), Design and Technology (D\&T) and Graphics Design. This gives learners a wide plethora of options when it comes to choosing career paths as long as the life span of the

Use of ICTS in schools also enables communication between school teachers and parents. In some instances, parents work or live far away from schools and cannot go to the schools regularly to get feedback on their children's schoolwork. Schools can communicate with parents through telephones, SMS, WhatsApp and or email. Effective communication through ICTS tools also helps in situations where there are challenges such as absenteeism, bullying and abuse at home.

\section{Use of ICTS in the field of healthcare}

In situations where distance is a challenge, delivery of health care services can be facilitated by ICTS (Ceo et al., 2013). This type of health care delivery is generally referred to as telemedicine (Bashshur, 1995). However, there are various definitions of telemedicine, which shows that the field is dynamic and is continually evolving in accordance with developments in technology (Ryu, 2012). ICTS-based technology enables diagnosis, treatment, and prevention of injury or diseases.

There are two types of telemedicine, synchronous and asynchronous. Synchronous telemedicine is done in real-time through the use of real-time media, e.g., skype, where both a medical expert and a patient are present for the diagnosis, treatment or prevention (Collins et al., 2000). Asynchronous telemedicine does not require the patient and the medical expert to be present at the same time (Ting et al., 2020). Diagnosis, treatment, or prevention is self-administered through the guidance of information that a medical expert provides (Ting et al., 2020). For example, when a patient sends an e-mail to a doctor to ask about a recent injury, the doctor does not necessarily have to read the email message immediately after it has been sent. The doctor responds to the treatment and management of the injury. Both types of telemedicine use media as mediums of information, e.g., text, images, audio, and video. For instance, biometric measuring equipment like devices that measure heart rate, blood pressure and blood glucose levels are used to monitor patients with chronic illnesses remotely (Ryu, 2012). Telemedicine has been used in radiology, cardiology, and dermatology. Tele-neurology is a branch of telemedicine that provides information and care to stroke patients in remote areas and aiding hospitals that lack experts or facilities to treat stroke patients appropriately 
(Bukhari et al. 2017). Another branch of telemedicine is tele-dentistry, which refers to use of ICTS in the field of dentistry (Bhargava et al., 2020). However, telemedicine services are offered more predominantly in developed countries than in developing countries (Murererehe et al., 2017).

\section{ICTS in Marketing}

As many people are increasingly getting reliant on ICTS for getting or disseminating information, businesses and organizations have to be responsive to these developments. Conventional methods of marketing on their own may no longer be effective for marketing purposes. Therefore, integrated marketing strategies, that take into account the importance of ICTS, are increasingly being used. Components of ICT that include internet, computers, mobile phones, cloud, etc. are important for marketing. Use of ICT for marketing purposes involves data mining, social media, websites, videos, podcasts, etc.

Data mining and analysis enables businesses and organizations to understand behavioural patterns of their clientele, clientele trends and market trends (Adomavicius and Tuzhilin, 2001) by extracting relevant information from large databases (Dadhich et al., 2016). This enables profiling of customers using customers' personal transactions, personal details and customer research. Customer profiles help companies and organizations to target and attract specific desired clientele. Other benefits of data mining are inquiry routine, e-mail filtering, on-line auctions and updating e - catalogues (Olmeda and Sheldon, 2002).

Social media, which is based on ICT, has become an integral part of most people's personal and business lives. Social media platforms include emails, SMS, WhatsApp, Instagram, Linked-in and Facebook. It is also an integral part of communication, entertainment and business (Essoungou, 2010). Accessibility of the internet on almost all devices like smartphones, iPads and laptops gives people access to information and knowledge wherever they are; hence distance has been removed as a barrier of communication. Marketers can use social media for brand advertising, introducing promotions or specials, getting feedback from clients, getting 'likes' from the public, etc. (Hoffman and Fodor, 2010). Social media has expanded its services to allow sharing of pictures, links, commenting, tagging and private messaging between users or the creation of group chats (Essays, 2017). ICTS is also commonly used in political marketing such as elections (Cheeseman and Klaas, 2018) for example, analysing and managing audience character with Social Media Marketing principles (Demydov et al., 2020).

\section{Use of ICT in E-Commerce}

E-commerce is the buying, selling or exchanging of goods via networks such as the internet (Hojeghan and Esfangareh, 2011). E-commerce is largely based on the internet which enables advertising, marketing, buying and selling online. ICTS has made online 
services possible, which have improved efficiency of businesses (Houghton, 2010). For example, a study conducted in Nairobi, the capital city of Kenya, showed that the use of mobile payments has resulted in significant growth of micro-businesses (Mbogo, 2010). However, there is a paucity of studies that focus on small businesses operating in rural areas.

Some commercial companies and restaurants make use of online delivery systems. Applications for various types of online services have been developed. For instance, apps enable customers to order online, mobile phones can be used to place orders and GPS on mobile phones enables navigation to the clients' locations. Payment for the delivered goods can be made through online methods and card or cash payment upon delivery. Virtual assistance like Amazon Alexa, Cortana, Viv, Cortana and Siri use voice search on search engine. Google has noted that more than twenty percent of mobile device searches are done using voice search (Sa and Yuan, 2020).

\section{ICTS and the Digital Divide}

ICTS and Digital divide refers to the unequal distribution of and access to information and communication (van Deursen and van Dijk, 2011). The cause of digital divide is the inability to afford the technology, lack of infrastructure (Mbatia, 2008), limited access to resources on the web and lack of access to networks (Camacho, 2005). Digital divide has been reported to negatively affect educational performance (Naidoo and Raju, 2012).

\section{Digital divide between developed and developing countries}

Although the overall use of ICTS is increasing, developing countries are lagging. For instance, there is no developing country in the top 30 countries on the ICTS Development Index (IDI) (Henry, 2019). In most African countries, there are high levels of poverty and low levels of education, which result in limited ability to afford or to use internet (Akanbi \& Akanbi, 2012). In South Asia only 4 people own PCs per 1000 people, but in the United States of America (USA), 546 people own PCs per 1000 people (Titilope, 2017). In Africa access to computers is less than other parts of the world; $10.7 \%$ of households in Africa own a computer (Statista, 2020). A recent International Telecommunication Union (ITU) report indicates that half of the world's population has access to internet and is able to go online but the other half cannot (ITU, 2018). Unfortunately, the larger proportion of the half that does not have access to internet is constituted by populations in developing countries (Henry, 2019). Considering the fact that ICTS forms a significant part of the foundation for the Fourth Industrial Revolution (Lukac, 2016), it implies that developing countries are likely to lag behind developed countries in terms of benefiting from the Fourth Industrial Revolution.

\section{The digital divide between urban and rural areas}


Just as there is a digital divide between developed and developing countries, there is a digital divide between populations in urban areas and those in rural areas. It has been reported that ICTS in rural areas has slow uptake due to the low to no income, lack of ICTS infrastructures, health statuses, cultural differences and many other reasons (Titilope, 2017). Some studies have shown that communities in rural areas in developing countries have limited access to electricity (Doll and Pachauri, 2010). It is estimated that 940 million people in the world did not have access to electricity in 2019, and the majority of them lived in rural areas, mainly in South Asia and Sub-Saharan Africa (Ritchie and Roser, 2019).

In most rural areas in developing countries, there are a few public access points for ICTS. Most of the few public access points in rural areas are not for free. Hence a limited number of people can afford to use them because they are poor. For instance, in Tanzania most of the public access points like internet cafes are privately owned and need to make a profit; hence, most rural households cannot afford to use the cafes (Furuholt and Kristiansen, 2007). However, some African countries like Rwanda have invested in improving access to internet not only in urban areas, but in rural areas as well (Ahmed, 2020). Due to the limited access to ICTS, most people in rural areas do not prioritize information, communication and technology because they have little or no income, hence they budget any meagre income they get for the most important needs like food, shelter, school fees for their children, health care and clothes.

\section{ICTS-based Rural Entrepreneurial Networks for socio-economic development of marginalized communities}

Many rural communities remain poor partly because they do not have the tools nor infrastructure to develop their economic situations. Some of the ICTS based tools that help to mitigate poverty are internet, mobile phones, televisions, radio, telephone fax and computers (Yekini et al., 2012), which all need electricity but most rural households do not have access to electricity. For example, sixty percent of households in rural South Africa do not have access to electricity (Jamal, 2015). Providing rural areas in developing countries with centralized grid-connected electricity is difficult due to the high service cost that most of rural communities cannot afford (Sievert and Steinbuks, 2020). However, African countries such as Malawi are overcoming these cost-related challenges and are connecting rural areas to grid electricity (Eales et al., 2020). Decentralized standalone systems or mini-grids are the most cost-effective electrification methods that are relatively affordable to rural households (Sievert and Steinbuks, 2020). For instance, solar-generated electricity can provide adequate electricity for basic ICTS tools.

With the limited access to electricity, the few ICTS tools that the majority of communities in rural areas can afford to get are mainly televisions, radios, mobile phones, telecentres and very limited internet kiosks or cafes (Shankar et al., 2020). However, 
utilization of those limited ICTS tools and limited access to internet for socio-economic development could be enhanced through various approaches and mechanisms.

One approach that could mitigate the challenges prevailing in rural areas in terms of utilization of ICTS is to establish Rural Entrepreneurial Networks (RENs) for various fields such as Agriculture, Arts and Culture, Education, Health and Business and Marketing in general. Establishment of RENs could be based on the specific social structures that are prevailing in the particular communities or nationalities. For instance, one social structure could start at village level and then progress through the district and provincial levels to the national level. At each level, there would be a champion or coordinator. Since there is diversity within and between communities in developing countries, the approach to be used in making use of ICTS should take into account individual social contexts of the communities (Miller, 2005). Therefore, the proposed approach of establishing RENs from the grassroots takes into account the different individual social contexts of the communities.

There may be networks in rural areas that may have been established and run by government departments or not-for-profit organizations, but the main challenge is sustainability since most of such networks last as long as there are funded projects. Having RENs that are established and run by rural communities themselves helps to enhance sustainability since the networks would be self-sustainable. Local community members would provide centres or nodes or cafes for such services as charging of phones using solar energy, basic computers for internet, emailing, typing, printing and scanning of documents.

\section{Agricultural Rural Entrepreneurial Networks to promote agricultural income-generating activities}

In many developing countries, agriculture is the main activity that produces food and generates income, especially in rural areas. The main type of farming done in rural areas is mainly subsistence done primarily to meet the needs of families. Subsistence farmers only sell their product when there is a surplus, but access to markets for their products is one of the challenges they face. Although use of ICTS by small holder farmers, who are usually located in peri-urban areas, has been reported (Nwafor et al., 2020), use by subsistence farmers in rural areas is relatively limited. However, there is increasing realization by subsistence farmers and governments that they could scale up their subsistence farming to small scale commercial farming. Since the main potential markets may be in urban areas that are far away from the rural farmers, ICTS helps to circumvent that challenge caused by the geographical locations of rural farmers.

Since individual farmers in rural areas may not have large quantities of agricultural products to offer for sale, it may not be cost effective for a farmer to transport his or her few products to places where there is demand for the products, which is mainly in urban areas. Similarly, it would not be cost-effective for potential buyers to travel long 
distances to farmers located in rural areas to buy small quantities of agricultural products. The REN coordinator would spearhead the process of identifying potential buyers, and over a period of time, a list of potential buyers would have been created. REN would enable farmers to firstly communicate and discuss products that are ready for sale and the quantities thereof. The information about the products ready for the market and quantities available would enable the REN coordinator to liaise with potential buyers. Details of when the products are to be gathered at one place either to be transported by the REN to the market or for the buyer to come and collect would be communicated through REN structures. Transporting agricultural products collaboratively and in bulk would help to reduce pertinent costs and work load because the farmers share the costs and the work load.

Various ICTS tools can be used for communication and networking. Mobile phones would be one of the basic tools for communication. To reach a wide range of farmers in the community, groups on applications like WhatsApp can be used. WhatsApp is a great application for people in rural areas as it is not as expensive as getting airtime to make phone calls or data to go online on social media platforms like Facebook. By getting in contact with other farmers in the area, they can share information about markets or businesses in need of various agricultural products.

In the wake of calls from various stakeholders and players for people to eat healthy food such as vegetables and fruits, agricultural RENs could take advantage of the growing demand for healthy food. Most farmers based in rural areas use traditional farming methods that rely on organic manure instead of fertilizers. Thus, they could produce and supply organic vegetables and fruits to the growing urban market. They also practice free range farming for such agricultural products as chickens, animals and dairy products. Agricultural RENs could get contracts to supply supermarkets that sell organic food.

The need for organic food is increasingly becoming a trend and hashtags have been created that the farmers could use to create awareness about the organic food they are able to provide. Some hashtags that have emerged on multiple social media platforms include \#EatingHealthy, \#EatingGreen, \#FarmFresh, \#LocalFarms and \#FreshPicked.

\section{Rural Entrepreneurial Networks for Arts and Culture}

Artists based in rural areas may not have platforms on which to expose their talents to the public and be able to generate income from their talents. There are artists in remote rural areas who make excellent artefacts using wood, stone, metals, clay and textile. As individual artists, it is generally costly to transport artefacts to urban areas where there is better market than in rural areas. Consequently, some artists are taken advantage of by some middlemen who buy the artefacts at very low prices and sell them in urban areas at huge profit margins. 
Rural Entrepreneurial Networks for Arts and Culture would form an effective platform for artists to enhance their income generating activities by providing cost effective ways of accessing potential markets. The RENs would ensure that the activities of the artists are coordinated and pricing is uniform and at acceptable levels. By making use of social media and eventually internet, artists can market their products without any need for middlemen, thus maximizing their profits. Gradually, the RENs could be so organized and effective that international buyers can be attracted and accessed. For example, there is anecdotal evidence that interest in African arts and culture has been increasing gradually and globally, arguably and partially due to movies like Black Panther, resulting in an increase in the demand for Afrocentric clothes. To make the most of the rising interest in African attire, many tailors and clothing companies invested in making dashikis and clothes made out of African print. They also used hashtags like \#BlackPanther, \#Duku, \#AfricanFashion and \#AfricanCulture to draw attention to their clothes. The RENs could also aim to get to that level and be able to compete not only nationally, but globally.

Other arts and cultural activities that could be marketed include drama, comedy, cultural dances, choir music, musical groups, and others. The performers could offer their entertainment services for such events as weddings, tourist destinations, religious gatherings, funerals, concerts, conferences and other social gatherings. Such exposure could lead to some performers clinching deals with recording companies or producers. The RENs would gradually build up databases of relevant players in the field of arts and culture for the benefit of their communities.

\section{Educational Rural Entrepreneurial Networks}

Education is critical for socio-economic development of communities. Use of ICTS in education in Africa has been reported, but has been implemented in urban area settings and in higher education (Vesisenaho et al., 2006). In general, schools in rural areas are not as well equipped and resourced as schools in urban areas. Consequently, pass rates for most schools in rural areas are relatively lower than pass rates for schools in urban areas. This is true for kindergarten, primary and secondary school levels. One of the big obstacles faced by schools in rural areas is limited access to ICTS tools that can help students to learn. Basic tools such as computers and internet which may be taken for granted in the urban areas are not readily accessible in rural areas. Educational Rural Entrepreneurial Networks could go a long way in alleviating some of the challenges.

Communication with parents of school going children is critical for schools to involve children's parents and guardians in the educational activities run by the schools. For instance, it is important for teachers to be able to communicate with parents about homework and or assignments that have been given to school children, especially primary school children, so that parents can monitor and ensure that their children do their school work. Educational RENs can facilitate this communication since information 
about a particular class or activity can be communicated through the structures of REN, thus preventing the need for the teacher to communicate with each and every parent individually.

The educational RENs could establish internet cafes where school children can go and use computers and internet to do their school work. If they are expected to submit hard copies of their school work, they can use the printing facilities retrieved from the cafes. That way school children would not be prevented from doing their school work and submitting for marking by lack of ICTS tools. However, the long-term goal should be for the schools to gradually use electronic methods of handling homework and assignments so that use of paper can be minimised.

\section{Rural Entrepreneurial Networks for promoting health of rural communities}

Poor health of communities compromises their socio-economic development. In order for any activities aimed at promoting the health of communities to be effective and sustainable, it is important for the communities to be actively involved so that they have a sense of collective ownership. While on one hand community members participating in the health-related activities will be helping to enhance the well-being of the community, on the other hand they may be generating income for themselves through the services they may be rendering.

Health care systems can make use of RENs since they would be rooted in the communities and hence would be capable of interacting with members of the communities effectively. One health-related activity that could be carried out by the RENs is dissemination of information such as antenatal care promotions, vaccination campaigns and disease prevention campaigns to fight such diseases malaria, cholera, TB, HIV/AIDS, and COVID-19 pandemic.

For instance, the COVID-19 pandemic that broke out in late 2019 showed the importance of information in terms of preventing and managing outbreaks of diseases. Having credible sources of information for members of communities, especially the marginalized ones who may not have the means to verify authenticity of information, is very critical in the fight against infections like the COVID-19 viral infections. Accurate information prepared and packaged appropriately by relevant authorities like Health Departments and other relevant organizations like the World Health Organization could be disseminated through RENs.

Accurate information about important preventative measures that have been scientifically proven to be effective at preventing viral respiratory tract infections such COVID-19 should reach all members of communities not only in urban areas but in rural areas as well. To circumvent the challenge caused by the remote locations of rural areas and limited availability of infrastructure, RENs could play a critical role in disseminating the accurate information that includes washing hands regularly and sanitizing hands (Rabenau et al., 2005); (Steinmann et al., 2010). Other methods of prevention are isolation, 
quarantine, social distancing and shutdown or lockdown to enable community containment (Wilder-Smith and Freedman, 2020). Statistics of confirmed cases, death toll and numbers of patients that have recovered should also be disseminated so that communities stay informed.

The RENs could also help to deliver medicines for chronic illnesses for the elderly people. This would be a community service that would be rendered jointly with the relevant government departments or ministries that are responsible for health and social welfare. The government would pay nominal fees for the services rendered by the RENs.

In cases of emergency, the RENs could enable speedy response by contacting the relevant authorities like the police or service providers like ambulances and fire brigade. The cases could be robberies, pregnant women going into labour, accidents, snake bites, natural disasters such as floods and others. Members of communities would know where to go in these cases of emergencies, and the RENs would have a list of all the important contact details.

\section{Rural Entrepreneurial Networks for Business and Marketing in general}

Communities in rural areas produce products and render services that may be needed within and between the same communities. This is in addition to the potential market emanating from urban areas. Thus, there are a lot of business opportunities that communities in rural areas can exploit for socio-economic development. However, if information about the products and services offered by the communities does not get to the potential market, the opportunities cannot translate into income generating business activities. Establishing RENs for business and marketing would enable communities to market products and services that they can offer.

The services that members of communities offer that could be marketed by the RENs include building, painting, thatching, welding, tailoring, dressmaking, plaiting hair, crocheting, carpentry, sinking wells and others. If a community member wanted to slaughter a cow for sale, the information could be disseminated through the REN so that on the day the cow is slaughtered, people who want to buy would come and buy. That way, the meat would be sold out and there would be no need to keep it for prolonged period of time, which may be a challenge since there may not be electricity for refrigeration.

For instance, the beauty industry could be a source of great income for communities in rural areas where some organic products are easily available. The same way that many people are interested in eating organic products is the same way that many people are interested in using beauty products without chemicals. This has increased interest in organically made products. The advent of Do It Yourself (DIY) has made many people to be interested in making their own beauty products. The DIY trend has increased the demand for beauty products like raw shear butter, black soap and Chebe, also known as croton (Salatino et al., 2007). Women in rural areas could use this 
as an opportunity to start selling organic beauty products online on platforms such as Facebook Market to urban areas or other rural communities.

Along with the DIY trend many people are interested in products and methods that certain communities use to preserve their beauty. For example, people have started using rice water after reports covering the potential of some antioxidant contents of red and white rice to protect and enrich hair and skin were published (Bopitiya and Madhujith, 2014). There are also reports of how Asians in rural areas use rice water to strengthen their hair and use it as a toner for their skin (Anushka, 2018). Rice water became popular because it is considered easy to make; hence, rice water is added to some products. If certain communities in rural areas have certain beauty routines that they use as DIY beauty products, they could film the process of making the products and also package the products for sell.

\section{References}

Adeyinka-ojo, S., Lee, S. and Teo, J. (2019) 'Hospitality and tourism education in an emerging digital economy education', Worldwide Hospitality and Tourism Themes. Emerald Publishing Limited, Vol. ahead(No. ahead-of-print). doi: 10.1108/WHATT-12-2019-0075.

Adomavicius, G. and Tuzhilin, A. (2001) ‘Expert-Driven Validation of Rule-Based User Models in Personalization Applications', Data Mining and Knowledge Discovery. Springer, 5(1/2), pp. 33-58. doi: 10.1023/A:1009839827683.

Agco, T. and Summit, A. (2012) 'for Agriculture in Africa', pp. 1-16.

Ahmed, F. R., Gebrechorkos and Solomon (2014) 'The Role of ICT in Water Resource Management.', in. International Telecommunication Union, p. 36.

Ahmed, I. (2020) 'Explaining Rwanda's prioritisation of rural electrification over rural clean drinking water through institutional path dependency', Structural Change and Economic Dynamics. North-Holland, 54, pp. 186-201. doi: 10.1016/j.strueco.2020.05.001.

Akanbi BE and Akanbi CO (2012) 'Bridging the Digital Divide and the Impact on Poverty in Nigeria', Information Systems \& Development Informatics, 3(4).

AlShrouf, A. (2017) 'Hydroponics, Aeroponic and Aquaponic as Compared with Conventional Farming | American Scientific Research Journal for Engineering, Technology, and Sciences (ASRJETS)', American Scientific Research Journal for Engineering, Technology, and Sciences, 27(1). Available at: https://asrjetsjournal.org/index.php/American_Scientific_Journal/article/view/254 3 (Accessed: 11 April 2020).

Anushka, F. (2018) Rice Water: The Cheap Secret To Growing The Longest Hair In The WORLD - Expert Home Tips, Expert Home Tips. Available at: https://experthometips.com/the-secret-to-growing-the-longest-hair-in-the-world 
(Accessed: 7 April 2020).

Bashshur, R. L. (1995) 'On the definition and evaluation of telemedicine.', Telemedicine journal : the official journal of the American Telemedicine Association, 1(1), pp. 19-30. doi: 10.1089/tmj.1.1995.1.19.

Bhargava, A. et al. (2020) 'Teledentistry: A literature review of evolution and ethicolegal aspects', Journal of Global Oral Health. Scientific Scholar, 2(2), pp. 128-133. doi: 10.25259/jgoh_68_2019.

Bhavani, M. (2020) 'A Study on Problems of Women Entrepreneurs at Mysore District, India', Our Heritage. Our Heritage, 68(1), pp. 9183-9200. Available at: https://archives.ourheritagejournal.com/index.php/oh/article/view/2280 (Accessed: 7 April 2020).

Bopitiya, D. and Madhujith, T. (2014) 'Antioxidant Potential of Rice Bran Oil Prepared from Red and White Rice', Tropical Agricultural Research, 26(1), pp. 1-11.

Buhalis, D. (1998) 'Strategic use of information technologies in the tourism industry', Elsevier Science, 19(5), pp. 409-421.

Bukhari, Syed, Ahmad, C., Khan, F. and Yousaf, Muhammad, N. (2017) Role of Telemedicine in Developed and Under-Developed Countries - IEEE Internet Initiative, IEEE Collabratec. Available at: https://internetinitiative.ieee.org/newsletter/may2017/role-of-telemedicine-in-developed-and-under-developed-countries (Accessed: 28 December 2017).

Camacho, K. (2005) 'Digital Divide', in Ambrosi, A., Peugeot, V., and Pimienta, D. (eds) Word Matters. 1st edn. C \& F Editions. Available at: https://vecam.org/archives/article549.html (Accessed: 25 March 2020).

Ceo, O. et al. (2013) 'Assessment of ICT Usage in Healthcare Service Systems: A Case Study of the Federal Medical Centre (FMC) Yenagoa in Bayelsa State, Nigeria', International Journal of Computer Science Trends and Technology , 6(1). Available at: www.ijcstjournal.org (Accessed: 7 April 2020).

Cheeseman, N. and Klaas, B. (2018) How to rig an election I Request PDF. Yale University Press. Available at: https://www.researchgate.net/publication/326982992_How_to_rig_an_election (Accessed: 14 June 2020).

Chib, A., Van Velthoven, M. H. and Car, J. (2015) 'MHealth adoption in low-resource environments: A review of the use of mobile healthcare in developing countries', Journal of Health Communication. Taylor and Francis Inc., 20(1), pp. 4-34. doi: 10.1080/10810730.2013.864735.

Collins, K., Nicolson, P. and Bowns, I. (2000) 'Patient satisfaction in telemedicine', Health Informatics Journal. Sage PublicationsSage CA: Thousand Oaks, CA, 6(2), pp. 8185. doi: $10.1177 / 146045820000600205$.

Dadhich, V., Vidhani, A. and Upadhyay, T. (2016) 'Customer Profiling and Segmentation using Data Mining Techniques', International Journal of Computer 
Science \& Communications, 7(2), pp. 65-67.

Demydov, I. et al. (2020) 'Development of basic concept of ict platforms deployment strategy for social media marketing considering tectonic theory', EUREKA, Physics and Engineering. Scientific Route, 2020(1), pp. 18-33. doi: 10.21303/24614262.2020.001101.

van Deursen, A. and van Dijk, J. (2011) 'Internet skills and the digital divide', New Media $\mathcal{E}$ Society. SAGE PublicationsSage UK: London, England, 13(6), pp. 893-911. doi: $10.1177 / 1461444810386774$.

Doll, C. N. H. and Pachauri, S. (2010) 'Estimating rural populations without access to electricity in developing countries through night-time light satellite imagery', Energy Policy. Elsevier Ltd, 38(10), pp. 5661-5670. doi: 10.1016/j.enpol.2010.05.014.

Donou-Adonsou, F. (2019) 'Technology, education, and economic growth in SubSaharan Africa', Telecommunications Policy. Elsevier Ltd, 43(4), pp. 353-360. doi: 10.1016/j.telpol.2018.08.005.

Eales, A. et al. (2020) 'Assessing the Market for Solar Photovoltaic (PV) Microgrids in Malawi', Journal of Sustainability Research. Hapres, 2(1). doi: 10.20900/jsr20200008.

Elias, E. C., Phillips, D. C. and Luechtefeld, M. E. (2012) 'E-books in the classroom: A survey of students and faculty at a school of pharmacy', Currents in Pharmacy Teaching and Learning. Elsevier Inc., 4(4), pp. 262-266.e1. doi: 10.1016/j.cptl.2012.05.009.

Essays, U. (2017) 'Social Media And Networking And The Role Media Essay', 17 Mei, pp. 3-5. Available at: https://www.ukessays.com/essays/media/social-media-andnetworking-and-the-role-media-essay.php.

Essoungou, A.-M. (2010) 'A social media book begins in Africa'. Available at: http://www.un.org/africarenewal/magazine/december-2010/social-media-boombegins-africa.

Fulk, J. and Connie Yuan, Y. (2017) 'Social Construction of Communication Technology', in The International Encyclopedia of Organizational Communication. Wiley, pp. 1-19. doi: 10.1002/9781118955567.wbieoc190.

Furuholt, B. and Kristiansen, S. (2007) 'A Rural-Urban Digital Divide?', The Electronic Journal of Information Systems in Developing Countries. Wiley, 31(1), pp. 1-15. doi: 10.1002/j.1681-4835.2007.tb00215.x.

Giles, J. (2018) What is ICT? What is the Meaning or Definition of ICT?, Michalsons. Available at: https://www.michalsons.com/blog/what-is-ict/2525 (Accessed: 26 March 2020).

Hartley, J. (2007) 'Teaching, learning and new technology: a review for teachers', British Journal of Educational Technology. John Wiley \& Sons, Ltd, 38(1), pp. 42-62. doi: 10.1111/j.1467-8535.2006.00634.x.

Henry, L. (2019) 'Bridging the urban-rural digital divide and mobilizing technology for poverty eradication: challenges and gaps'. St Augustine. 
Hoffman, D. D. L. D. L. and Fodor, M. (2010) 'Can You Measure the ROI of Your Social Media Marketing?', MIT Sloan Management Review, 52(1), pp. 41-49. doi: 10.1287/mksc.1120.0768.

Hojeghan, S. B. and Esfangareh, A. N. (2011) 'Digital economy and tourism impacts, influences and challenges', Procedia - Social and Behavioral Sciences. Elsevier B.V., 19, pp. 308-316. doi: 10.1016/j.sbspro.2011.05.136.

Houghton, J. (2010) 'ICT and the environment in developing countries: opportunities and developments', The Development Dimension ICTs for Development: Improving Policy Coherence, 6(October 2009), p. 149. Available at: http://www.oecd.org/dataoecd/40/3/44005687.pdf.

ITU (2018) Measuring the Information Society Report Executive summary 2018 ITUPublications Statistical reports Executive summary.

Jamal, N. (2015) 'Options for the supply of electricity to rural homes in South Africa', Journal of Energy in Southern Africa, 26(3). Available at: http://www.scielo.org.za/scielo.php?script=sci_arttext\&pid=S1021447X2015000300006 (Accessed: 18 March 2020).

Kabbiri, R. et al. (2018) 'Mobile phone adoption in agri-food sector: Are farmers in SubSaharan Africa connected?', Technological Forecasting and Social Change. Elsevier Inc., 131, pp. 253-261. doi: 10.1016/j.techfore.2017.12.010.

Kavoura, A. and Stavrianea, A. (2014) 'Economic and Social Aspects from Social Media's Implementation as a Strategic Innovative Marketing Tool in the Tourism Industry', Procedia Economics and Finance. Elsevier B.V., 14(14), pp. 303-312. doi: 10.1016/S2212-5671(14)00717-5.

Komendantova, N., Schinko, T. and Patt, A. (2019) `De-risking policies as a substantial determinant of climate change mitigation costs in developing countries: Case study of the Middle East and North African region', Energy Policy. Elsevier Ltd, 127, pp. 404-411. doi: 10.1016/j.enpol.2018.12.023.

Lee, D. and Derrible, S. (2020) 'Predicting Residential Water Demand with MachineBased Statistical Learning', Journal of Water Resources Planning and Management. American Society of Civil Engineers (ASCE), 146(1), p. 04019067. doi: 10.1061/(ASCE)WR.1943-5452.0001119.

Lukac, D. (2016) 'The fourth ICT-based industrial revolution "industry 4.0" - HMI and the case of CAE/CAD innovation with EPLAN P8', in 2015 23rd Telecommunications Forum, TELFOR 2015. Institute of Electrical and Electronics Engineers Inc., pp. 835-838. doi: 10.1109/TELFOR.2015.7377595.

Mandi, K. and Patnaik, N. M. (2019) 'Mobile apps in agriculture and allied sector : An extended arm for farmers', Agriculture Update, 14(4), pp. 334-342. doi: 10.15740/HAS/AU/14.4/334-342.

Mbatia, P. (2008) Education and Information \& Communication Technologies (ICT) in Africa: Using ICT to improve education in Sub-Saharan Africa. Available at: 
https://www.researchgate.net/publication/264847406 (Accessed: 6 April 2020). Mbogo, M. (2010) 'The Impact of Mobile Payments on the Success and Growth of MicroBusiness: The Case of M-Pesa in Kenya', Journal of Language, Technology $\mathcal{E}$ Entrepreneurship in Africa. African Journals Online (AJOL), 2(1), pp. 182-203. doi: 10.4314/jolte.v2i1.51998.

Miller, J. (2005) Perspectives and Policies on ICT in Africa. Hout Bay. Milton, S. et al. (2016) 'Numerical weather prediction over Africa', in Diop - Kane, M. and Parker, D. J. (eds) Meteorology of Tropical West Africa: The Forecasters' Handbook. 1st edn. Chichester, UK: wiley, pp. 380-422. doi: 10.1002/9781118391297.ch10.

Mohammed, A. et al. (2017) 'E-Learning : A Tool for Enhancing Teaching and Learning in Educational Institutes', 8(2), pp. 217-221.

Moliner, M. A. et al. (2007) 'Relationship quality with a travel agency: The influence of the postpurchase perceived value of a tourism package', Tourism and Hospitality Research. SAGE PublicationsSage UK: London, England, 7(3-4), pp. 194-211. doi: 10.1057/palgrave.thr.6050052.

Murererehe, J. et al. (2017) 'Knowledge, attitude and practices of dental professionals in Rwanda towards the benefits and applications of teledentistry', Rwanda Journal. African Journals Online (AJOL), 4(1), p. 39. doi: 10.4314/rj.v4i1.6f.

Naidoo, S. and Raju, J. (2012) 'Impact of the digital divide on information literacy training in a higher education context', South African Journal of Libraries and Information Science. Stellenbosch University, 78(1). doi: 10.7553/78-1-46.

Nwafor, C. U., Ogundeji, A. A. and van der Westhuizen, C. (2020) 'Adoption of ICTBased Information Sources and Market Participation among Smallholder Livestock Farmers in South Africa', Agriculture. MDPI AG, 10(2), p. 44. doi: 10.3390/agriculture10020044.

Olmeda, I. and Sheldon, P. J. (2002) ‘Data mining techniques and applications for tourism internet marketing', Journal of Travel and Tourism Marketing. Taylor \& Francis Group , 11(2-3), pp. 1-20. doi: 10.1300/J073v11n02_01.

Olson, M. K. et al. (2019) 'Build community before the storm: The National Weather Service's social media engagement', Journal of Contingencies and Crisis Management. Blackwell Publishing Ltd, 27(4), pp. 359-373. doi: 10.1111/1468-5973.12267.

Rabenau, H. F. et al. (2005) 'Efficacy of various disinfectants against SARS coronavirus', Journal of Hospital Infection. W.B. Saunders, 61(2), pp. 107-111. doi: 10.1016/j.jhin.2004.12.023.

Ritchie, H. and Roser, M. (2019) 'Access to Energy', Our World in Data.

Rohila, A. K., Yadav, K. and Ghanghas, B. S. (2017) 'Role of Information and communication technology (ICT) in agriculture and extension', Journal of Applied and Natural Science. ANSF Publications, 9(2), pp. 1097-1100. doi: 10.31018/jans.v9i2.1328.

Ryu, S. (2012) 'Telemedicine: Opportunities and Developments in Member States: 
Report on the Second Global Survey on eHealth 2009 (Global Observatory for eHealth Series, Volume 2)', Healthcare Informatics Research, 18(2), p. 153. doi: 10.4258/hir.2012.18.2.153.

Sa, N. and Yuan, X. (Jenny) (2020) 'Examining users' partial query modification patterns in voice search', Journal of the Association for Information Science and Technology. John Wiley and Sons Inc., 71(3), pp. 251-263. doi: 10.1002/asi.24238.

Salatino, A., Salatino, M. L. F. and Negri, G. (2007) 'Traditional uses, chemistry and pharmacology of Croton species (Euphorbiaceae) ', Journal of the Brazilian Chemical Society. Sociedade Brasileira de Quimica, 18(1), pp. 11-33. doi: 10.1590/S0103-50532007000100002.

Schwalbert, R. A. et al. (2020) 'Satellite-based soybean yield forecast: Integrating machine learning and weather data for improving crop yield prediction in southern Brazil', Agricultural and Forest Meteorology. Elsevier B.V., 284, p. 107886. doi: 10.1016/j.agrformet.2019.107886.

Shankar, A., Elam, A. B. and Glinski, A. (2020) 'Strengthening the women's entrepreneurship ecosystem within the energy sector', IDS Bulletin. Institute of Development Studies, 51(1), pp. 27-52. doi: 10.19088/1968-2020.104.

Shanker, D. (2008) ICT and Tourism: Challenges and Opportunities. Kozhikode.

Shobhana and Gill, S. K. (2019) 'Impact of Information Technology in the Growth of Tourism Industry', International Journal of Research and Analytical Reviews, (Special Issue), pp. 330-333. Available at: http://ijrar.com/ (Accessed: 7 April 2020).

Sievert, M. and Steinbuks, J. (2020) ‘Willingness to pay for electricity access in extreme poverty: Evidence from sub-Saharan Africa', World Development. Elsevier Ltd, 128, p. 104859. doi: 10.1016/j.worlddev.2019.104859.

Statista (2020) Share of households with a computer in Africa 2005-2019 I Statista, Statista. Available at: https://www.statista.com/statistics/748549/africa-households-withcomputer/ (Accessed: 14 June 2020).

Steinmann, Jochen et al. (2010) 'Virucidal activity of 2 alcohol-based formulations proposed as hand rubs by the World Health Organization', American Journal of Infection Control, 38(1), pp. 66-68. doi: 10.1016/j.ajic.2009.07.009.

Sugg, M. M., Fuhrmann, C. M. and Runkle, J. D. (2020) ‘Perceptions and experiences of outdoor occupational workers using digital devices for geospatial biometeorological monitoring', International Journal of Biometeorology. Springer, 64(3), pp. 471-483. doi: 10.1007/s00484-019-01833-8.

Sun, S., Law, R. and Luk, C. (2020) 'Tourists' Travel-Related Information Search Channels', International Journal of Hospitality and Tourism Administration. Routledge, pp. 1-16. doi: 10.1080/15256480.2020.1727809.

Takahashi, K., Muraoka, R. and Otsuka, K. (2020) ‘Technology adoption, impact, and extension in developing countries' agriculture: A review of the recent literature', Agricultural Economics. Blackwell Publishing Ltd, 51(1), pp. 31-45. doi: 
10.1111/agec.12539.

Theunissen, I. (2015) E-agriculture: How ICT is taking farming into the future I IT News Africa - Africa's Technology News Leader, IT News Africa. Available at: http://www.itnewsafrica.com/2015/11/e-agriculture-how-ict-is-taking-farminginto-the-future/ (Accessed: 15 January 2018).

Ting, D. S. et al. (2020) 'Next generation telemedicine platforms to screen and triage', British Journal of Ophthalmology. BMJ Publishing Group, 104(3), pp. 299-300. doi: 10.1136/bjophthalmol-2019-315066.

Titilope, A. O. (2017) ‘Digital Divide and its Socio-Psychological Implications on Rural Dwellers in Nigeria', International Journal of Innovation in the Digital Economy. IGI Global, 9(1), pp. 26-34. doi: 10.4018/ijide.2018010103.

Topp, S. N. et al. (2020) 'Research Trends in the Use of Remote Sensing for Inland Water Quality Science: Moving Towards Multidisciplinary Applications', Water. MDPI AG, 12(1), p. 169. doi: 10.3390/w12010169.

Vesisenaho, M. et al. (2006) 'Contextualizing ICT in Africa: The Development of the CATI model in Tanzanian Higher Education', African Journal of Information $\mathcal{E}$ Communication Technology. University of Technology, Sydney (UTS), 2(2), p. 88. doi: 10.5130/ajict.v2i2.23.

Wilder-Smith, A. and Freedman, D. . (2020) 'Isolation, quarantine, social distancing and community containment: pivotal role for old-style public health measures in the novel coronavirus (2019-nCoV) outbreak I Journal of Travel Medicine I Oxford Academic', Journal of Travel Medicine, 27(2). Available at: https://academic.oup.com/jtm/article/27/2/taaa020/5735321 (Accessed: 7 April 2020).

Yazdekhasti, S. et al. (2020) 'Sustainability Analysis of a Leakage-Monitoring Technique for Water Pipeline Networks', Journal of Pipeline Systems Engineering and Practice. American Society of Civil Engineers (ASCE), 11(1), p. 04019052. doi: 10.1061/(ASCE)PS.1949-1204.0000425.

Yekini, N. A. et al. (2012) 'Ict "Tools" for Poverty Eradication and Economic Growth in Nigeria', Greener Journal of Educational Research. Greener Journals, 2(1), pp. 013019. doi: 10.15580/gjer.2012.1.gjer1202.

Yonazi, E. et al. (2012) The Transformational Use of Information and Communication Technologies in Africa. 1st edn, The Transformational Use of Information and Communication Technologies in Africa. 1st edn. World Bank. doi: 10.1596/26791. 